\title{
新しい発色系
}

1. はじめに

約 130 年前，イギリスのパーキンが“モーブ”を合成 して以来，種々の発色系を持つ化合物が次々と開発され， 現在では世界で 9000 種類にのはるる染料がColour Index に登録されている。1980 年代に入って，本特集に見ら れる様な色素の光吸収, 光放射, 光化学反応, 光導電活 性などを利用する新しい用途の開発が活発になり，従来 の色素に新しい機能を見い出す多くの検討がなされてき た ${ }^{1)}$ 。また既存の染料母体を基本にさまざまの工夫を加 えて高性能の染料を開発しようという努力上, さらに新 しい発色系を見い出そうという努力も依然として続けら れている。本稿では主に友料用染料の分野で開発されて きた発色系を概観すると共に最近見い出されてきた新し い発色系饥いて述べる。

\section{2. 色と構造}

染料の色と構造についてはWittの発色団説の提唱から 始まり，共鳴理論により大きな発展をとげた。最近では Hückel 法やPariser-Parr-Pople 法(PPP法)などの 分子軌道法による理論的定量的説明がなされ，色と構造 の関係は次第に明らかになってきており 2$)$ ，今後は，新し い発色系の合成デザインにも応用されるあのと思われる。

\section{1 アソ系染料}

グリースによるジアゾ化カップリング反応の発見に始 まるアゾ染料は現在でも全染料の約 $60 \%$ を占め, 種類, 色共に豊富で最も重要な種属である。

アゾ染料の発色系は電子供与性基 (Donor) と電子吸引 性基 (Acceptor) がアゾ基により連結されているいわゆ る分子内電荷移動型発色系をとる。次の一般式(1)で表 わされる発色系において $\mathrm{A}, \mathrm{A}^{\prime}, \mathrm{A}^{\prime \prime}$ に $-\mathrm{NO}_{2},-\mathrm{CN}$,

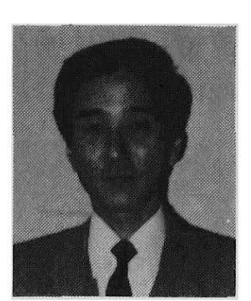
$-\mathrm{Cl},-\mathrm{COOCH}_{3}$ 等の電子吸引基 を,またD, D'に- $\mathrm{CH}_{3},-\mathrm{OCH}_{3}$,

New Chromophore 究所 主任研究員 ついて述べていただいた。
西 栗 正 夫<smiles>[Y6]c1cc([Y9])c(N=Nc2cc([2H])c(N([R])[R])cc2[2H])c([Y9])c1</smiles>

- $\mathrm{NHCOCH}_{3}$ 等の電子供与性基を導入すると澡色移動す る。この置換基効果は従来の共鳴理論では説明できなか ったが，分子軌道法による計算の結果，定量的説明が可 能となった。表 1 に示すようにアゾベンゼン系染料につ いてPPP-MO 法により求めた第一励起エネルギー $\left(\Delta E_{1}\right)$ と実測值がよく一致していることが確かめられている゚゙。

表 1

\begin{tabular}{|c|c|c|}
\hline 置 換 基 & $\begin{array}{c}\text { 計算值 } \\
\Delta E_{1}(\mathrm{eV})\end{array}$ & $\begin{array}{c}\text { 実験値 } \\
E_{\max }(\mathrm{eV})\end{array}$ \\
\hline $3-\mathrm{NH}_{2}$ & 3.336 & 3.35 \\
\hline $4-\mathrm{NH}_{2}$ & 3.443 & 3.42 \\
\hline $4-\mathrm{NHCH}_{3}$ & 3.202 & 3.21 \\
\hline $4-\mathrm{N}\left(\mathrm{CH}_{3}\right)_{2}, 4^{\prime}-\mathrm{NO}_{2}$ & 2.912 & 2.79 \\
\hline $4-\mathrm{N}\left(\mathrm{CH}_{3}\right)_{2}, 3^{\prime}-\mathrm{NO}_{2}$ & 3.069 & 2.96 \\
\hline $4-\mathrm{N}\left(\mathrm{C}_{2} \mathrm{H}_{5}\right)_{2}, 2^{\prime}-\mathrm{CN}$ & 2.843 & 2.72 \\
\hline $4-\mathrm{N}\left(\mathrm{C}_{2} \mathrm{H}_{6}\right)_{2}, 3^{\prime}-\mathrm{CN}$ & 3.021 & 2.88 \\
\hline $4-\mathrm{N}\left(\mathrm{C}_{2} \mathrm{H}_{5}\right)_{2}, 4^{\prime}-\mathrm{CN}$ & 2.871 & 2.74 \\
\hline
\end{tabular}

次に，アゾ染料に関する最近の研究傾向について述へ る。

モノアゾ染料に関しては鮮明化を図るために化合物 〔2〕，〔3〕のようにアゾ基のオルト位にアシルアミ/基 を，ジアゾ成分に 2 個のシア/基を導入する試みがな れている4）。シルアミノ基がアゾ基あるいはシアノ基 との水素結合により，環状構造をとるためと解釈される。

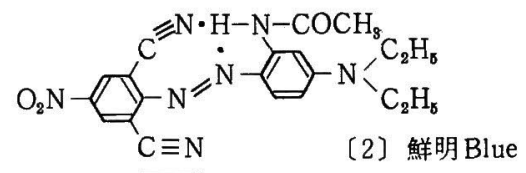

筆者紹介 MASAO NISHIKURI, SUMITOMO CHEMICAL CO. LTD., 住友化学工業(株)大阪砛

筆者は，有機合成化学が尃門で，染料及びその中間体の合成に携わっている。趣味は山步き。

本稿では，衣料用染料分野で開発されてきた発色系を概観すると共に，最近見出された新しい発色秋 
<smiles></smiles>

鮮明化，深色化之共にカラーバリューもすぐれるとい う特街をもつために，ジアゾ成分にへテロ環を導入する 試みか数多くされており゙，またカップリング成分にへ テ口睘を使用する例も多くみられる

ヘテロ環ジアゾ成分の例<smiles>[R]c1nnc(C)s1</smiles><smiles>O=[N+]([O-])c1ccc2ncsc2c1</smiles><smiles>COc1cc([N+](=O)[O-])cs1</smiles><smiles>Cc1sc([N+](=O)[O-])cc1[N+](=O)[O-]</smiles>

ヘテロ環カップリング成分の例<smiles></smiles><smiles>[R]N([R])c1nc(C2C=CC=C2)c(C)s1</smiles>

次にへテロ環を使用した染料例をあげる゙,6)。<smiles>[R10]c1ccccc1CN(CCCC)c1ccc(N=Nc2nc(C#N)c(C#N)n2C)c(NC=O)c1</smiles>

(4) Red

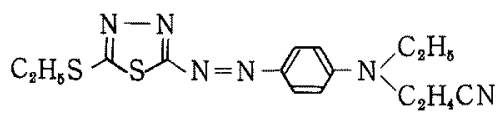

(5) Red<smiles>CCN(CC)c1cc(N=Nc2nnc([N+](=O)[O-])s2)c(OC)cc1NCO</smiles>

(6) Greenish Blue<smiles>CCN(CC)c1ccc(N=Nc2sc([N+](=O)[O-])cc2[N+](=O)[O-])c(NC(C)=O)c1</smiles>

[7] Bluish Green<smiles>COS(=O)(=O)Oc1cccc(N=Nc2c(O)[nH]c(=O)c(C#N)c2C)c1</smiles>

[8] Yellow<smiles></smiles>

(9) Red<smiles>CCOC(=O)Nc1cc2c(cc1N=Nc1c(C#N)cc([N+](=O)[O-])cc1[N+](=O)[O-])C(C)CC(C)(C)N2CC</smiles>

(10) Blue

ヘテロアリ゙染料についてもPPP-MO法に上る $\lambda_{\max }$ の 計算值と実測值はよく一致している゙っ。

表 2 Calculated (PPP) and experimental $\lambda_{\max }$ values for some heterocyclic azo dyes.

\begin{tabular}{|c|c|c|}
\hline Het & $\lambda_{\max } \mathrm{C}_{6} \mathrm{H}_{12}(\mathrm{~nm})$ & $\lambda_{\max }$ calc. $(\mathrm{nm})$ \\
\hline & 547 & 547 \\
\hline & 448 & 440 \\
\hline & 533 & 539 \\
\hline & 476 & 467 \\
\hline & 471 & 474 \\
\hline & 510 & 505 \\
\hline
\end{tabular}

深色化のあう一つの方法であるアり゙基の数を增やす例 においておへテロ環を導入する例が最近增加している。<smiles>C=CCN(CC=C)c1ccc(N=Nc2sc(N=Nc3ccccc3)cc2C#N)cc1</smiles>

(11) Navy Blue ${ }^{\text {s) }}$ 
<smiles>[R]n1c(O)c(N=Nc2ccc(N=Nc3ccccc3)cc2)c(C)c1C#N</smiles>

(12) Golden Yellow ${ }^{9}$

\section{2 キノン系染料}

アントラキノン系染料は分子吸光係数はアゾ系より低 いものの鮮明性, 安定性にすぐれ, 赤, 青, 青緑のよう な深色用染料として重要な地位を占めている。アントラ キノン系についてもPPP-MO法による計算の結果得ら れた第一励起エネルギーと最長波長吸収带の $\lambda_{\text {max }}$ 加引み つもった $\Delta E_{\max }$ が良い一致をみている゙0)。

また， 1ーアミノアントラキ/ンの場合，アミノ基を 含むべンゼン骨格をドナー。ナフトキノン骨格をアクセ プター上する分子内電荷移動型発色系であると指摘され ている ${ }^{2 a)}$ ○アントラキノン染料は[13]，〔14]の上うに 1，2，4一置換あるいは1，4，5８一置換染料が基本であるが，<smiles>Nc1c(Oc2ccccc2)cc(O)c2c1C(=O)c1ccccc1C2=O</smiles><smiles>C=C1C(=O)c2c(N)ccc(Br)c2C(=O)c2c(O)ccc(Br)c21</smiles>

$\mathrm{NH}_{2} \mathrm{O} O H$ (14) C.I.Disperse Blue 56

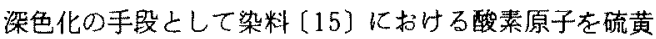
原子に置換する試みがなさ札ている゙1。

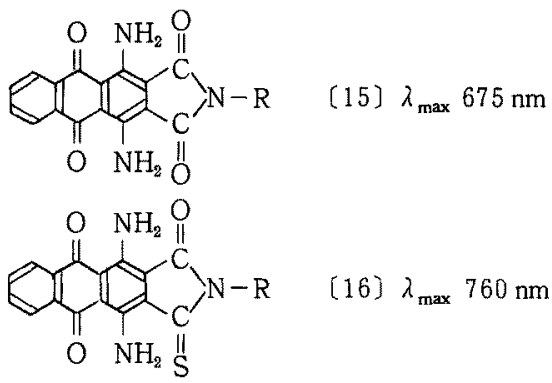

ナフトキノン采色素についても同様の計算結果が報告 されている ${ }^{12)}$ 。即ち，アクセプターがナフトキノンの代 わりにp-ベンゾキノンとなるため，対応するアントラ キノン系色素より深色的になっており，2，3位にシア， 基などの電子吸引性基を導入するとさらに㳭色的になり， 赤外吸収色素としての利用が期待されている ${ }^{13)}$ 。

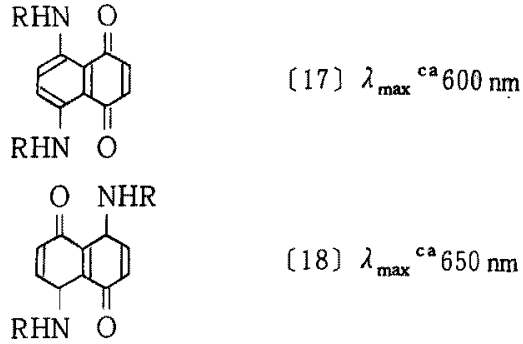<smiles>N[14NH2]</smiles><smiles>N#CC1=C(C#N)C2C=CC=CC23CCCCC3C1=O</smiles>

DHN O

また、ナフトキノン骨格に，より強力なドナーとしで 硫黄原子を導入する試みすなされている゙4。<smiles>O=C1C=CC(=O)C2C(Nc3ccccc3)=C(Nc3ccccc3Sc3ccccc3Sc3ccccc3)C(=O)C12</smiles>

(20) $\lambda_{\max } 725 \mathrm{~nm}$

\section{3 縮合系染料}

スチリル系染料はドナーーアクセプター発色柔をとる ことは知られているが，てれにシアノ基を導入するとと により，顕著な深色効果を伴うこと加見い出されている。 [21 b]上り $[21 \mathrm{c}]$ へは実に $80 \mathrm{~nm}$ 以上の梁色移動が 察される。

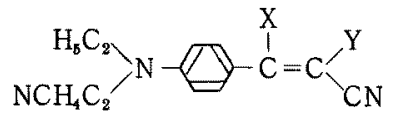

a. $\mathrm{X}=\mathrm{Y}=\mathrm{H} \quad \lambda_{\max } 362 \mathrm{~nm}$ 無色

b. $\mathrm{X}=\mathrm{H}, \mathrm{Y}=\mathrm{CN} \quad \lambda_{\max } 422 \mathrm{~nm}$ Yellow

c. $\mathrm{X}=\mathrm{Y}=\mathrm{CN} \quad \lambda_{\max } 507 \mathrm{~nm}$ Red

同じ考え方をクマリン系に応用すると同樣に大幅な深 色化加達成できる ${ }^{15)}$ 。即ち，(22a)は強い蛍光をむつ黄 色染料であるが，[22b]は学光性の赤色染料となる。

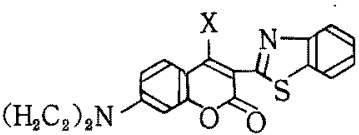

a. $\mathrm{X}=\mathrm{H} \quad \lambda_{\max } 452 \mathrm{~nm}$

b. $\mathrm{X}=\mathrm{CN} \lambda_{\max } 519 \mathrm{~nm}$ クマリン系の縮合睘をさらに拡大した $(23 a)$ は強い虽光 をもつ赤色染料であるが，とれにシアノ基を導入した [23b]は鮮明な青色染料となる ${ }^{16)}$ 。 


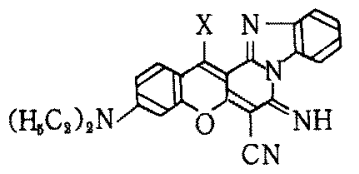

a. $\mathrm{X}=\mathrm{H} \quad \lambda_{\max } 540 \mathrm{~nm}$

b. $\mathrm{X}=\mathrm{CN} \lambda_{\max } 630 \mathrm{~nm}$

またアアクセプターとしてジシアノメチレン基の導入

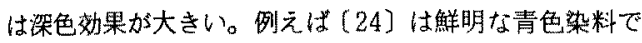
モ儿眨光保数は70,000亿達している ${ }^{16)}$ 。

$$
\prod_{\mathrm{O}_{2}}^{\mathrm{CN}}=\mathrm{CH}-\underbrace{\mathrm{NC}}_{\mathrm{CH}_{3}}-\mathrm{N}\left(\mathrm{C}_{6} \mathrm{H}_{13}\right)_{2}
$$

その他、シシアノメチレン基学入した例として[25], (26]、〔27〕などがすげられる。<smiles></smiles><smiles>CCN(CC)c1ccc(C=c2sc(=C(C#N)C#N)nc2-c2ccccc2)cc1</smiles>

(26) Greenish Blue ${ }^{18)}$<smiles>CC1CC(C)(C)N(/C=C/c2ccccc2)c2ccc(C(=O)NC(=O)NC(C#N)=C(C#N)C#N)cc21</smiles>

(27) Greenish Blue ${ }^{18}$

メチン系の新しい発色系として，ビスアニル化合物 [28]，およよ゙ブタジェン誘導体 [29]が見い出されてい る。

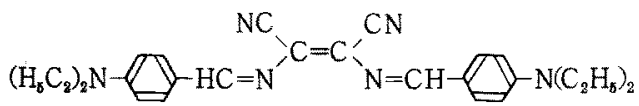
$(28]^{20)} \operatorname{Red}$

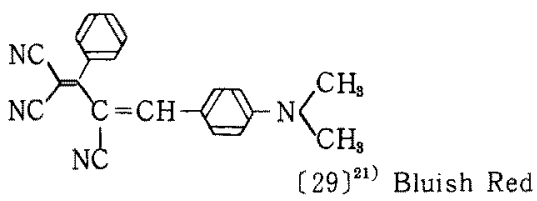

インジゴ $(30]$ はH部電子供与基， $\mathrm{C}=\mathrm{O}$ 部を電子 受容基とするいわ的るH型発色系と呼ばれる交叉共役型 の発色系で単純な構造であるが，深色性を示す。

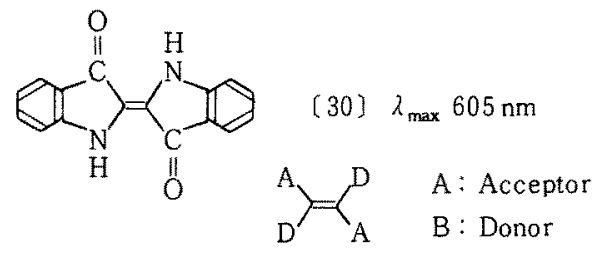

同じような交叉共役型の発他系をもつ化合物としてべ

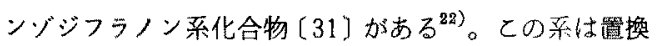
基Xの影響索大きく受け，色調はオレンシ色から緑色ま で変化する。㫷本の発色系は右側化示した通りである。

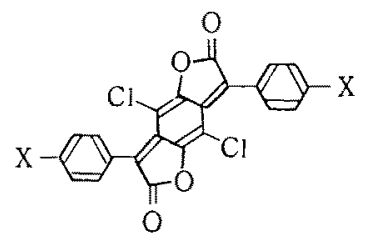
a. $\mathrm{X}=\mathrm{H}$
Yellow
b. $\mathrm{X}=\mathrm{OCH}_{\mathrm{s}}$ Red
c. $\mathrm{X}=\mathrm{N}\left(\mathrm{C}_{2} \mathrm{H}_{5}\right)_{2}$ Greenish Blue<smiles>[2H]c1ccc(C([2H])([2H])C)cc1</smiles>
ビスアリールチオキノンジイミン系化合物 (32]， [33] もPPP-MO法による計算で交叉共役型発色系であるこ とが確認されている ${ }^{23)}$ 。

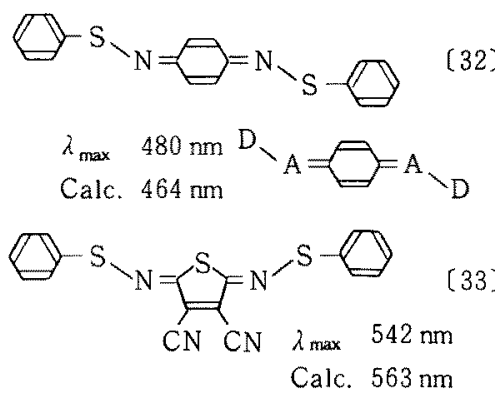

(31)と〔32〕を組み合わせた〔34]ばモル㠷光保数が

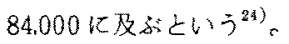

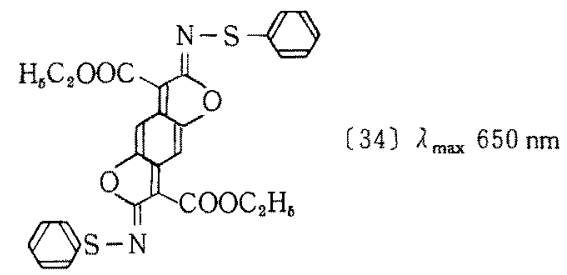

さらに最近見い出された新しい交叉共役型発色系に 〔35〕、〔36〕があげられる。 


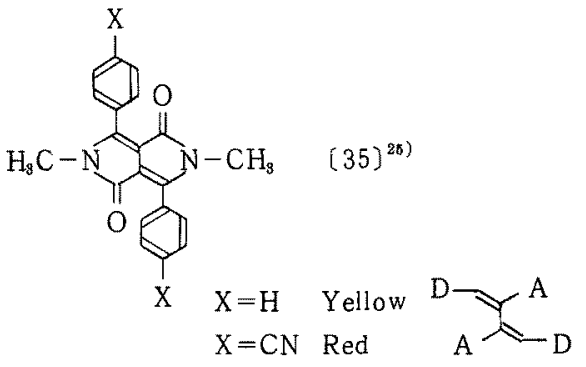

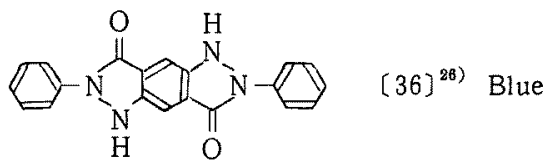

その他，縮合系化合物としてはナフタル酸系染料 [37]， ナフトラクタム系染料〔37\}などがあげられる。

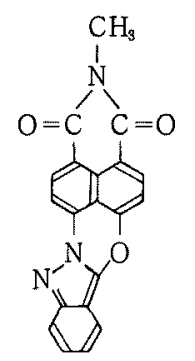

(37〕 ${ }^{27)}$ 鮮明 Yellow<smiles></smiles>

$(38]^{28)}$ 鮮明 Red

また，反応染料の発色母体として，次に示すトリつ。 ハジオキサジン系 [29]，ホルマザン系[40]，キサンテ ン采〔41]化合物が検討されている。

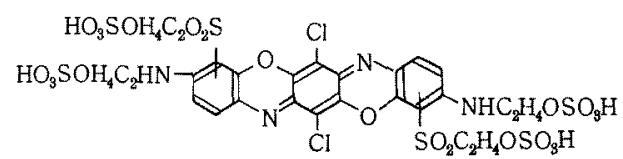

〔39〕 ${ }^{29)}$ 鮮明 Blue

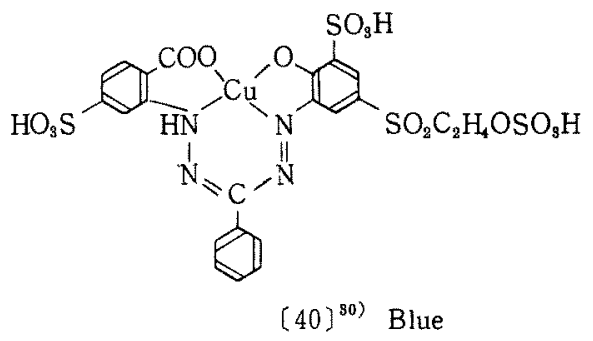

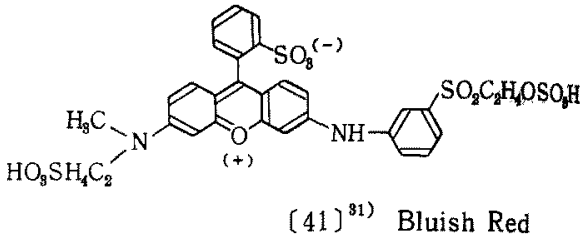

3.おわりに

染料に抢りる基本発色系については 20 世紀前半まて に主なむのは開発されていたとはいうすのの，その後も 鮮明さ、コストメリット等を求めて新しい発色系の袜索 は連綿として綕けられている。本稿ではその一部しか級 介できなかったが，今後の研究の参考になれ涬いであ る。機能性色素の場合，比較的付加洒值の高いあの加多 いので, 说来に比へ発色系の研究範囲は抎がるであろう。 また，過去に打いて新しい発色系の発見は偶然によるて とが多かったが，今後は過去の知識，経駼をもとに分子 軌道法等の理論的裏つけも考慮した展開かなされていく ものと思われる。

\section{文献}

1）大河原，黑木，北尾編：“機能性色素の化学” ーエムシー (1981)

池森，住谷: “特殊機能色素”シーエムシー (1986)

2) a. J. Griffiths: "Colour and Constitution of Organic Molecules" Academic Press (1976)

b. J. Fabian, H. Hartmann: "Light Absorption of Organic Colorants" Springer-Verlag (1980)

3）古後，菊地：日本化学会誌，1979，1524

4) Bayer：特公昭 44-24707。特開昭 53-113830

5) M. A. Weaver, L. Shuttleworth: Dyes Pigments, 3, 81 (1982)

6) H. R. Schwander: Dyes Pigments, 3, 133 (1982)

7) J. Griffiths: "Development in the Chemistry and Technology of Organic Dyes", Blackwell Scientific Publication Oxford (1984)

8) Eastman Kodak: USP 4374768 (1983)

9) Ciba-Geigy: 特開昭 58-185652

10) Y. Kogo, H. Kikuchi, M. Matsuoka, T. Kitao: J. Soc. Dyers Colour., 96, 475 (1980)

11）日本化薬：特開昭 58-219262

12) K. Y. Chun, J. Griffiths: J. Chem. Soc. Perkin I, 1979, 696

13) K. Y. Chun, J. Griffiths: J. Chem. Res., 1978, 2319

14) Y.Takagi, M. Kawabe, M. Matsuoka, T. Kitao, Dyes Pigments, 6, 1777 (1985) 
15) P. Moeckli: Dyes Pigments, 1, 3 (1980)

16) Sandoz: 特開昭 55-34288

17) BASF：特開昭 55-131064

18) BASF：特開昭 54-19974

19) 住友化学: 特開昭 60-156760

20) Du Pont: 特開昭 50-98928

21）日本化嵲：特開昭 $60-226555$

22） ICI：特開昭 52-109526，56-122869

23) C. W. Greenhalgh et al.: J. Chem. Res., 1982, 138
24) L. Cheng, C. W. Greenhalgh: J. Chem. Res., 1983, 28

25) Ciba-Geigy: 特開昭 60-35056

26）東洋曹達: 特開昭 $60-92356$

27) 三菱化成：特開昭 54-18832

28) Ciba-Geigy: 特開昭 51-107329

29) Bayer: 特開昭 60-184567

30) Hoechst: 特開昭 56-76462

31) Hoechst: 特開昭 57-44671

(昭和 61 年 12 月 1 日受理)

\section{光化学ホールバーニング (PHB)}

次世代の光記録技術としてPHB (Photochemical Hole Burning)記録が注目されて いる。現状の光記録では，用いる光の波長が

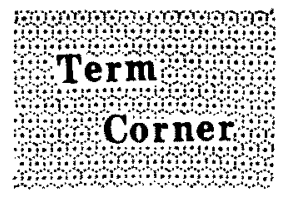

保存温度の向上，2）外部場摄動効果，3） 感度の向上，についての基礎的研究がすすめ られている。工技院の次世代産業基盤技術 「光反応材料」の 1 つのテーマとしてもとりあ げられている。(大阪大学・産研入江正浩)

$800 \mathrm{~nm}$ 付近であるととを考えると、スポット径は〜 $1 \mu \mathrm{m} \phi$

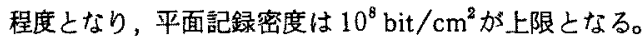
記録密度を更に上げるには，同一スポット内での多重記 録が必要になる。その1つが波長多重書き込みを用いた PHB記録であり， $10^{11} \mathrm{bit} / \mathrm{cm}^{2}$ 記録が可能之考元られて いる。PHB とは，光吸収分子をポリマーや有機溶媒の マトリックス中に分散させ，極低温状態 $\left(4^{\circ} \mathrm{K}\right)$ におき， その吸収スペクトルヘ、レーザーからの波長の巾の狭い 単色光をあてる之，その単色光を吸収する分子代だけ光 化学反応が起き，巾広いその吸収スペクトルの一部にホ ールがあく現象をいう。この現象を利用すれば，照射す る単色光の波長を変えることにより，巾広いスペクトル 巾中にいくつものホールをあけるととが可能になり，そ れぞれ指定した波長に捛いてホールの有無を0，1ビット に対応させれば，1 つのスポット中に多重記録が可能に なる。いかなる光化学反応でも $\mathrm{PHB}$ が可能であるかと いうとそうではなく，励起状態のポテンシャルが，基底 状態のそれに似ていることが必要であり，てのための反 応系の探索が続けられている。有機系としては，キニザ リン類，ポルフィリン．フタロシアニン系での水素移動, プラズマディスプレイ

2 枚のガラス電極基板で構成される空間 (約 $0.1 \mathrm{~mm}$ ) に，Neを主体上する希ガスを数百Torr 封入し，希ガス のプラズマ放電に伴うマトリクス電極交点での発光を利 用したディスプレイ。色は赤橙色である。多色化の研究 も進められている。（日本化桼的松永代作）

$$
\mathrm{E} \cdot \text { เディスプレイ }
$$

硫化亜鈶などの母体材料比発光中心として Mn（黄橙 色), $\mathrm{Cu}$ (赤), $\mathrm{TbF}_{\mathrm{s}}$ (緑色) などを添加した蛍光体発光 首に電生を印加して発光する現象を利用したディスプレ

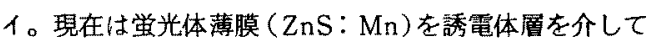
電極間にはさんだ三層構造に，交流電印を印加し動作さ せる交流形薄膜 ELD が一般的である。営光体㸴之誘電 体層の界面に蓄積される電子に基つくメモリ機能がある のが特徽。

（日本化楽 松永代作） 